\title{
手の外傷の治療経験 特に開放創の初期治療について
}

\author{
新日鉄八幡製鉄所病院整形外科 \\ 吉田光男・橘寛
}

新日鉄八幡製鉄所病院形成外科

碓 井良弘

内村整形外科

内 村 正 英

田中整形外科

田中 力

久富整形外科

$$
\text { 久富孝弘 }
$$

\section{Primary Treatment of Open Hand Injury}

by

\author{
M. Yoshida, H. Tachibana
}

Department of Orthopaedic Surgery

Y. Usui

Department of Plastic Surgery

Nippon Steel Corporation Yawata Works Hospital

\section{Uchimura}

Uchimura Orthopaedic Clinic

C. Tanaka

Tanaka Orthopaedic Clinic

\section{T. Hisatomi}

Hisatomi Orthopaedic Clinic

It is important to make open hand injuries with wide crushed wound healed primarily. Pedicle skin grafting has been done for this purpose. However, a risk of infection and a difficulty in supporting the arch of hand in this method are the problems to be solved.

Trimming the wound edge to make a small and single-formed skin defect is essential for primary wound healing.

One of the causes of deformity and pseudoarthrosis after multiple injuries of hand is to start exercising befor a bone union is not completed.

It has been cleared that firm fixation of the fractured bone independently from the neighboring joints is necessary.

はじめに

手は人間の日常生活及び職業労働にきわめて重要な
役割をはたすが，また外傷を受けやすい器官である. 手の新鮮開放性損傷に対する初期治療の適否, 特に開 放創の一期癒合に成功するか否かは，機能を再建する 
上に重大な影響をもっている．化膿は絶対に防止しな ければならない。もし化膿がおこれば，それは最初の 処置が不適当であったためだと言われている.しかし wringer injury, degloving injury では, その初期 治療はきわめてむづかしく，一期癒合，感染の防止に 成功するととは困難なととが多いととす指摘されてい る.われわれは過去 5 年間に minor injuries を除 くと，手の外傷 97 例の治療を行なった，をれを損傷 別にみると, 開放骨折 23 例, 非開放性骨折 12 例, 脱 臼骨折 2 例, 開放性脱臼 2 例, 挫創 28 例, 指 (手部) 不全切断 10 例, 指切断 20 例となっており, 97 例 中 83 例 $(85.5 \%)$ は開放創を伴っていた，乙れらの開 放創の大多数では一期窑合に成功しているが，wringer injuries 飞類する高度の挫滅を受けた症例で は，一期癒合に成功することはきわめてむづかしいて とを知らされた，ここでは一期漓合が成功した場合 と，そうでない場合について代表的な症例をあげての べ, 若干の考察を加える，また一期澸合に成功した場 合に於いても, 多数指重度損傷の機能の再建にはむづ かしい問題があり，それについてあ触れたい.

\section{症}

例

症例 129 才 男子 左示指基節部不全切断. 左示 指を機械にはさまれて受傷した，同指は基節中央で一 部の軟部組織を残し挫滅切断されていて，それょり末 梢は循環障害を示していた（眓 $1 \mathrm{a}$ ). 幸い尺側の神 経血管策は損傷を免がれていたので，骨折をキルシュ ナー鋼線で整復位に固定すると, 末梢部の循環は改善 をみた，挫滅された皮虞は一次縫合を行なったが，壊 死に陥ったので, Debridement を行ない, 指背部は 縫縮, 指掌側は cross finger flap で被覆した. 創 閉鎖，骨癒合ともに順調で，PIP 関節は良肢位で固 定されていることを除いてほぼ問題ない手に回復して いる(図 $1 \mathrm{~b}$ ).

症例 230 才 男子 左手高度挫隇創. 左手を機械 にはさまれて受傷した (図 2 a). 中指は中節より末 梢が, 環指, 小指は末節が著るしく挫隇していたので 切断せざるを得なかった. 示指は掌側の皮虔が剝脱し て, 屈筋腱が露出していたが，骨折や屈筇腱の損傷は 無かった. 㸚脱した皮膚は可及的に元に戻し，挫滅の 著るしい組織は切除して, 皮膚欠損部には遊離植皮を 行なった。一部皮膚は壊死飞宿ったので, 再度壊死組 織の Debridement を行ない, 遊離植皮で被覆して

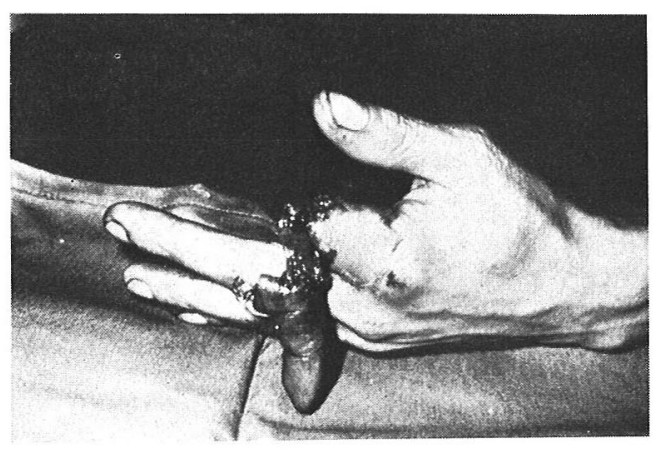

a. 来院時所見

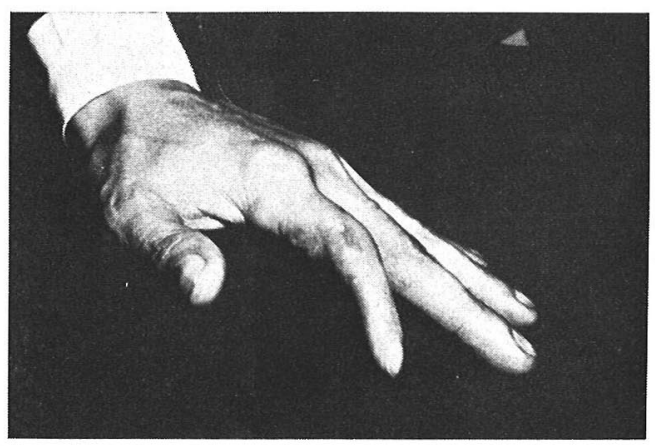

b。術後所見

図 1 (症例 1)

創閉鎖が得られた．示指の PIP 関節の届曲障害が認 められ，その原因が pulley の欠損によるあのであっ たので，創洀痕が軟化するのを待って，二次的に pul ley の再建を行ない，殆んご問題のない手に回復する ことが出来た（図 2 b).

症例 333 才 男子 左手ローラー損傷. 左手を前 腕末端まで金属製のローラーに巻き込まれて受傷した (図 3 a). 筋膜切開の後, 患肢を挙上飞保って経過を みたが，左手は前腕末端以下著るしく腫脹し，拇指を 除いて殆んど全部の皮膚が壊死に宿った，手掌部を切 開してみると，殆んど出血が認められず，遊離植皮の 母床としては不適当であった. しかし再建について考 えれば，出来るだけの骨格を確保する必要があったの で, 示指, 中指, 環指, 小指は PIP 関節で離断し, 関節軟骨を切除して遊離皮弁で被覆した. しかしその 遊離皮弁は術後 3 日目に笑如循環障害を起とし, 壊死 に宿った. そこで groin flap で末梢部を, 中枢側は 遊離植皮で被晋した，手を広範に有荃植皮で被覆する ためには，極めて大きな皮弁を必要とし，また茎部を 完全に閉鎖することは困難である. 従って感染を起こ 


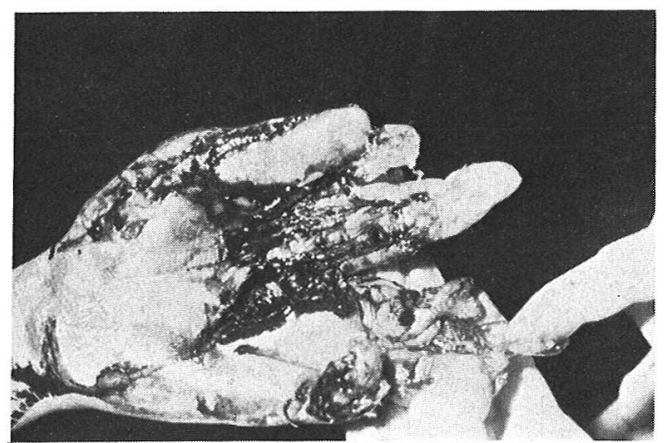

a. 来院時所見

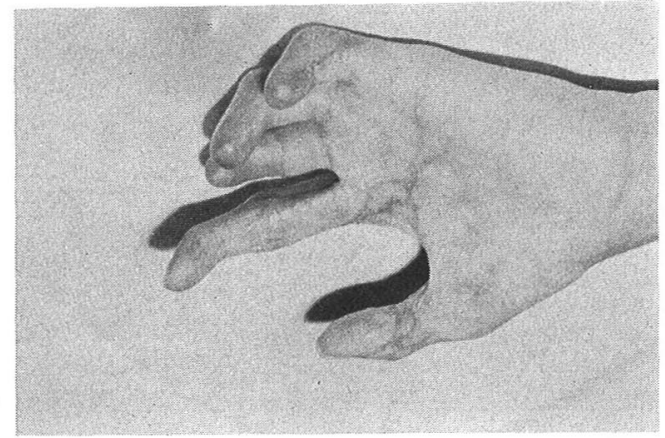

b. 術後所見

図 2(症例 2)

した．また手のほぼ全部を皮弁で被覆する場合，手の 横, 縦のアーチを良肢位に固定することは殆んど不可 能である. この症例は手の横, 縦のアーチの欠如, 特 に拇指対向位障害, 感染によって増強された線維化, その結果おこる stiffnessという問題をかかえ, 現在 二次再建にそなえて筋力増強を主としたリハビリテー ションを行なっているとてろである（図 $3 \mathrm{~b}$ ）.

症例 429 才 男子 左手ローラー損傷. 印刷の輪 転機に左手をはさまれて受傷した，左手全体は全く手 の形体を失なうような著るしい損傷を受けていて，損 傷を受けた軟部組織の中には，一面真黒いグリース様 の物が混入していた（図 4 a). 始ず創を逆性石ケン を用いて充分に scrubbing を行ない, 異物の付着し た組織や挫減した組織を八サミで切除し，生食水で充 分に洗浄した. しかし黒いグリース様の異物を完全に 除去することは到底不可能であった，骨格を元の位置

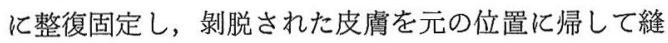
合した.

この際皮膚のかなりの部分が壊死に宿いるだろうこ

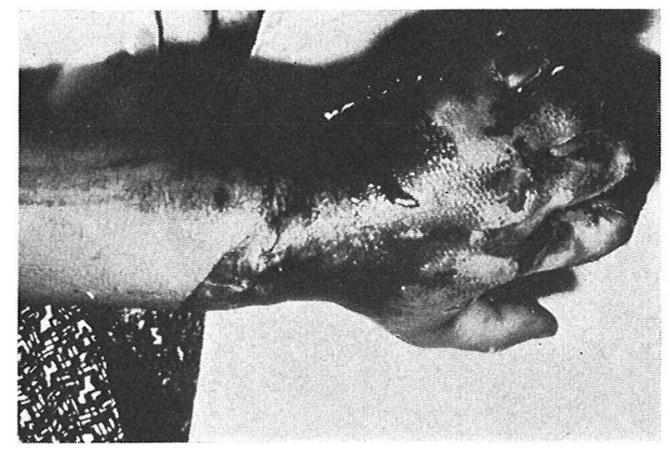

a. 来院時所見

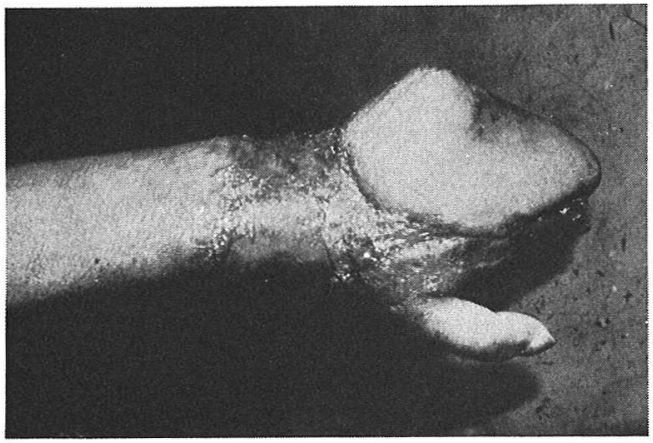

b. 植皮術後

図 3 (症例 3)

とは予想されたが，ぞれだけの部分を切除すべきか判 断がつかず, 壊死の恐れがあるところを完全に切除し てしまうには広過ぎた．またそうすると遊離植皮に不 適なところが多く出て来て，その被覆はまた一段とむ づかしい問題となることは明らかであった，従ってと りあえず剝脱した皮㲊を元に戻して縫合し，経過をみ るより他に方法はなかった．皮膚の壞死は手背の大部 分と, 手掌では幅 1 2 cm の唗死が 手掌を横断する あの之, 縦断するあのが手掌中央で交叉するような形 にあり, 縦の皮膚壊死は中指へと続き, 中指は中節よ り末梢ではその大部分が，また示指の背側で基節と中 節部にそれぞれ壞死が㧍てった. 皮膚壊死が広範かつ 複雑な形状を呈していたので，まず最む広い手背に， 次に手掌から中指に有茎植皮を行なったが，手掌から 中指の有茎植皮の際に感染をおこし, 示指基節の骨髅 炎へと発展するとととなった，示指基節背側の皮膚壞 死は皮弁で修復し，骨髄炎の治療を続けたが，結局そ の治療のために治療期間が長びくととになり，治瘾の 目処がたたないので，示指基節骨を摘出し，示指末梢 


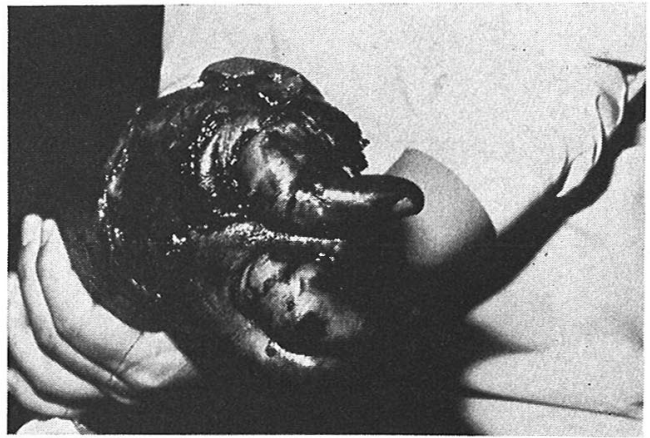

a. 来院時所見

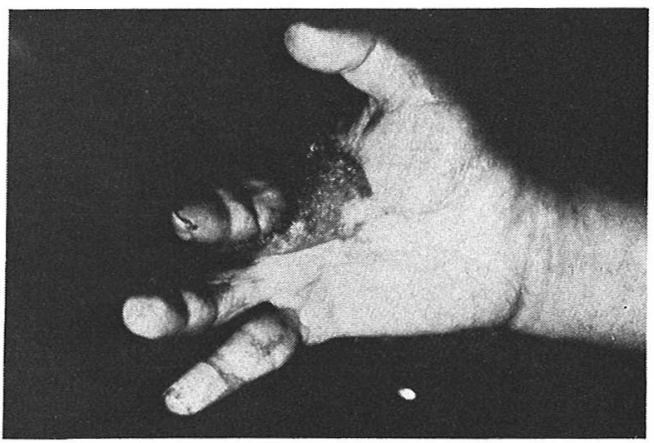

b. 術後所見

図 4（症例 4)

部を，壊死となって失った中指中節以下に移して中指 の延長を行なった（図 $4 \mathrm{~b}$ ).

症例 563 才 男子 右中手部不全切断. 電気ノコ で中手部を尺側より第 2 指列に至るまで横切する外傷 を受けた（図 5 a). 第 3 , 第 4 , 第 5 中手骨は切断 部で横切されていて, 中指, 環指, 小指の循環障害が 認められた. 直ちに再植術を行ない, 総掌側手動脈 2 本，静脈 1 本の血管吻合，尺骨神経浅枝の縫合を行な った. 腱の再建については, 浅指屈筋腱を切除し, 樑 指屈筋腱を引き寄せるにとどめ, 二次的に行なった. 受傷後 4 年 2 力月の follow up 時, 患手は著るしい 変形拘縮を示し示指がM P 関節でかなりの可動性を残 す他は, 中指, 環指, 小指の M P 関係でわずかの可動 性を認める以外, PIP 関節, DIP 関節での可動性は 全く認められなかった. しかしそれにあ拘らず，拇指 之示指とで side pinch を上手に行ない, 中指, 環 指, 小指はその際示指を支える働きを果し, 著るしい 変形, 著るしい関節運動障害があるにも拘らず, 紐結 び，ネクタイ結び，ナイフを用いた果物の皮むき等の 動作を行なうととが出来た（図 5 b).

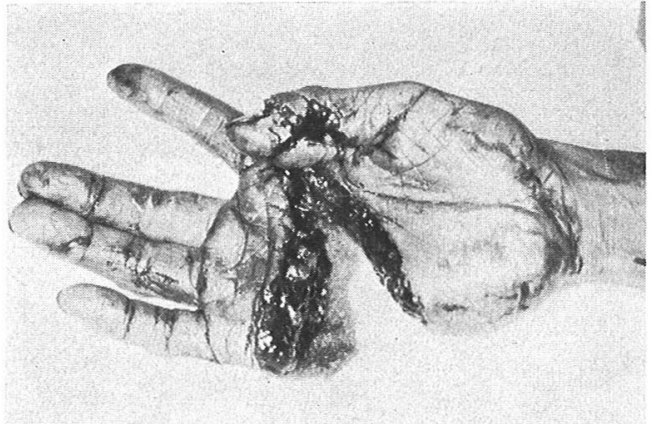

a. 来院時所見

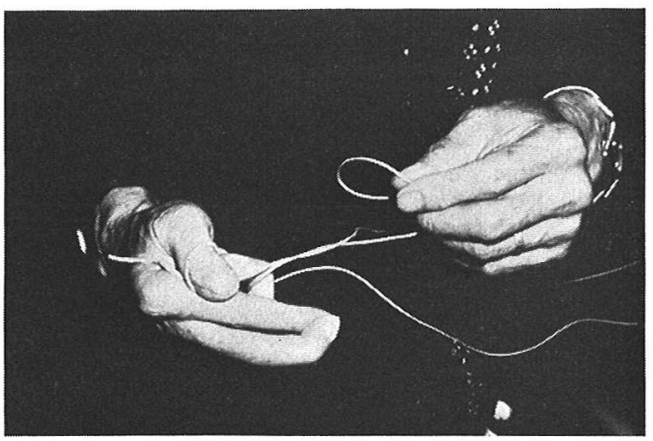

b. 術後所見

図 5(症例 5)

考案

津下はその著書の開放創の処置の章の冒頭に，開放 創の処置のもっとも大切なととは，一期癒合に成功す ることであると述べている. 手の開放創が一たび感染 をおこすと，機能の再建に重大な影響を及ぼすととは 多くの人々が強調するとてろである. 開放創の治療の 原則は今更言うまであないととであるが，創を徽底的 に scrubbing を行ない, surgical debridement 加え，更に saline cleansing を行なう. 皮膚欠損 部には直ちに遊離植皮で被覆し, 遊離植皮が不適な場 合には有茎植皮によって創の闒鎖をはかり，感染をお こすととなく，創を一次的に治癒せしめるととであ る. 開放創が極く小範囲に限られているときは上記の 処置を行なえば殆んぞまちがいなく，一次的に治癒せ しめることが出来る. 有茎植皮が必要な場合にも何ら むづかしい問題はない，しかし挫滅が広範に及ぶ開放 創では事情が全く違ってくる. wringer injury, degloving injury の開放創を一次的に治癒せしめるこ とはきわめてむづかしいととである. 手の開放創の治 
療で一期癒合の重要性が強調されている一方では, 開 放創の中にはその一期癒合に成功することがきわめて むづかしいものがあるところに，乙の種の外傷の治療 のむづかしさがある. 症例 $1 ， 2$ は一期瘁合に順じて 創閉鎖に成功した症例で，速やかに良好な機能を持つ 手に回復することが出来た. 一方症例 3,4 は感染を おこし, 治療の長期化の他に, 再建に当たってむづか しい問題を残すこととなった. 症例 2 は手全体が著る しく挫滅されていたにも拘らず良好な経過をとったの は, 皮膚の損傷が手掌側及び指尖部に限られ，指尖部 を切断すると, 開放創は手掌側に限局していて，また 遊離植皮が可能な母床が得られたことが治療を容易に した. 一方症例 $3 ， 4$ は皮膚壊死が広範におこり，そ の被覆法は容易ではなかった，両症例之も有茎植皮を 必要としたが，いづれも感染をおこしてしまった，症 例 4 は最初の有茎植皮を手背に行なったのであるが, 相当大きな欠損であったけれどあ, 形状が単純であっ たので，茎部を完全に閉鎖することが出来て，感染を 起こさずに行なうことが出来た. しかし創が広範でか つ複雑な形状を呈している開放創を被覆するにはきわ めて大きな皮弁を必要とし, 茎部を閉鎖するてとが出 来ず，感染はまず避けられない，またそのような有茎 植皮を行なう際には, 手の縦, 横のアーチを保持する ことは殆んど不可能である. 重度挫滅の手を治療する に当っては, 機能の再建をどのように行なうかをあら かじめ考えておく必要があり，骨格を整復位に固定 し，縦横のアーチを保持することは機能の再建上きわ めて重要なことである. しかし大きな有荃皮弁を用い なければならない時には, 感染防止及びアーチの保持 が困難であるという問題を伴うあのであるから，指長 を短縮するとか，一指を切断するとかして被覆面積を 小さくすることあ場合により考慮すべきてとであろ う. また被覆部を出来るだけ単純な形状に変え, たと え茎部に開放創が残っても，手の被覆部は $100 \%$ 皮弁 により被覆し，感染がおこっても，その影響を被覆部 に及ぼさないようにすべきである.

重度損傷手には著るしい変形や関節拘縮を残すこと が少なくない，挫滅創を伴う骨折では，骨癒合が遷延 することはめずらしくないが，そのような手は stiffness あ著るしく，それを出来るだけ早く回復訓練を 始めることによって改善せしめようとするために，多 数指骨折の場合は, 一部骨瘉合が不充分のまま回復訓 練を行ない, それが偽関節, 変形の発生の原因となっ
ていることがあった，骨折を隣接関節とは独立的に強 固に固定をすることの重要性を指摘したい.

変形や拘縮が著るしい手であってあ, 驚くほど上手 に使いてなしている症例を見た．手の潜在的な代償能 は驚くべき大きなあのと思われる.

$$
\text { ま と め }
$$

手の開放創の初期治療について述べた. 手の開放創 は一期瘉合を期するととが最も重要であるが，広範な 挫滅がある開放創を一次的に治癒せしめることは大変 むづかしい．有茎植皮には感染の危険と手のアーチを 保有することの困難性が伴っている. 出来るだけ被覆 面積を小さく，また被覆部を出来るだけ単純な形にし て被覆することが大切である. 多数指損傷手では変形 や偽関節がよくみられるが，内固定が不充分な手を， 骨癒合が不充分な時に動かすことが原因となることが ある. 内固定を隣接関節とは独立的に強固に行なうこ との重要性を指摘した。

\section{文献}

1）赤堀 治: 手部開放性損傷と切断, 災害医学, 21: 769-775, 1978.

2）赤堀 治: 手部新鮮開放性損傷の治療成績とそ の反省, 災害医学, 20：1191-1197，1977.

3) 東 博彦: 骨 - 関節外傷と感染症, 災害医学, 15: 143-151, 1972

4) Holevich, J.: Early Skin Grafting in the Treatment of Traumatic Avulsion Injuries of the Hand and Fingers, J. Bone and Joint Surg., 47-A ; 944-957, 1965.

5）板谷博之：四肢新鮮外傷における感染の治療と その予防法，災害医学，15：255-259，1972.

6）木野義武：手の外傷初期治療の問題点一不適切 な初期治療の予後とその再建術の検討加ら, 災害 医学, 20:1095-1100, 1977.

7）三浦隆行：四肢高度損傷の治療，上肢および手 の高度損傷の治療一再建法とその限界, 日本災害 医学誌, $27: 281-288,1979$.

8）三浦隆行：多数指基部切断例の機能再建, 整形 外科, 20:37-41, 1969.

9）室田景久：手の外傷の初療, 災害医学, 15: 269-282, 1972.

10）長野健治：手部高度開放性損傷の治療一第一 報, 総論, 災害医学, 12:37-47, 1969.

11）難波碓哉：上肢の外傷一特飞複雑損傷の初期治 療, 災害医学, 15: 283-290, 1972.

12）南条文昭：手指外傷の術後経過について, 災害 医学, 17: 287-292, 1974. 
13）荻原一輝：我々の行なっている delayed primary suture について, 災害医学, 12: 78-83, 1969.

14）杉本 倪：四肢外傷と感染症一特に軟部組織損 傷, 災害医学, 15：136-141，1972.

15）津下健哉：手の外科の実際，昭和 49 年改訂第 5 版, 南江堂, 東京.

16）津下健哉： 複雑な手の損傷とその機能再建,
治療方針の立て方とその実施，整形外科，17： 1047-1061, 1966.

質 問 福岡大整形 高岸 直人 指の切断は患者の意志によって決定するということ であるが, Medical な面と衝突することはないか. 